\title{
ANALISIS KUAT SUMBER NEUTRON DAN PERHITUNGAN LAJU DOSIS NEUTRON TERAS AWAL RDE
}

\author{
Suwoto, Hery Adrial, Zuhair \\ Pusat Teknologi dan Keselamatan Reaktor Nuklir - BATAN \\ Kawasan Puspiptek, Serpong, Tangerang Selatan, 15314 \\ e-mail : suwoto@batan.go.id
}

(Naskah diterima: 12-11-2016, Naskah direvisi: 19-01-2017, Naskah disetujui: 20-01-2017)

\begin{abstract}
ABSTRAK
ANALISIS KUAT SUMBER NEUTRON DAN PERHITUNGAN LAJU DOSIS NEUTRON TERAS AWAL RDE. Teras reaktor RDE (Reaktor Daya Eksperimental) berbentuk silinder non anular, berbahan bakar kernel partikel berlapis TRISO yang berbentuk bola (pebble) dan berpendingin gas helium. Desain teras reaktor ini sangat aman karena mengadopsi teknologi reaktor temperatur tinggi HTGR (High Temperature Gas-cooled Reactor) dengan keselamatan inheren pasif. Temperatur keluaran gas helium teras reaktor dirancang pada kisaran $700{ }^{\circ} \mathrm{C}$ dengan temperatur masukan sekitar $250{ }^{\circ} \mathrm{C}$. Di samping menghasilkan listrik, reaktor didisain menghasilkan panas temperatur tinggi yang dapat digunakan untuk keperluan kogenerasi lainnya (penelitian panas proses lainnya). Bahan bakar reaktor berbentuk bola yang berisikan kernel partikel berlapis TRISO yang berupa uranium dioksida $\left(\mathrm{UO}_{2}\right)$ berpengkayaan $17 \%\left({ }^{235} \mathrm{U}\right)$. Lapisan TRISO terdiri 4 lapisan yaitu lapisan karbon penyangga berpori, lapisan karbon pirolitik bagian dalam (IPyC, Inner Pyrolitic Carbon), lapisan Silikon Karbida (SiC) dan lapisan pirolitik karbon bagian luar (OPyC, Outer Pyrolitic Carbon). Analisis kuat sumber dan perhitungan awal laju dosis neutron pada RDE dilakukan menggunakan program Monte Carlo MCNP5v1.2. Pemodelan heterogenitas ganda bahan bakar dilakukan pada bahan bakar kernel partikel berlapis TRISO dan pada bahan bakar bola pada teras reaktor. Pemanfaatan program EGS99304 untuk menentukan jumlah struktur group energi yaitu 640 (SAND-II group structure) yang digunakan dalam perhitungan spektrum neutron pada reaktor. Teras reaktor dibagi dalam 100 zona (10 arah radial dan 10 arah aksial). Analisis hasil perhitungan menunjukkan bahwa kuat sumber neutron reaktor sebesar $8,47027 \times 10^{17}$ neutron/detik. Distribusi laju dosis neutron ditentukan menggunakan faktor konversi fluks neutron ke dalam dosis neutron dari International Commission on Radiological Protection (ICRP) dan National Council on Radiation Protection and Measu-rements (NCRP). Hasil perhitungan awal laju dosis neutron dengan faktor konversi ICRP21 dan NCRP-38 untuk pekerja radiasi pada arah radial di perisai biologis sudah melemah memberikan nilai masing-masing sebesar 6,69915 $\mu \mathrm{Sv} / \mathrm{jam}$ dan 6,9964 $\mu \mathrm{Sv} / \mathrm{jam}$ pada posisi 215 $\mathrm{cm}$ dari pusat teras reaktor. Hasil analisis ini mengindikasikan bahwa pekerja radiasi aman dan terlindungi dari sumber radiasi neutron sesuai dengan persyaratan regulasi yang berlaku. Secara keseluruhan, dari hasil analisis perhitungan tersebut tampak bahwa model perisai radiasi dan perisai biologis telah memenuhi standar keselamatan radiasi yang dipersyaratkan. Hasil penelitian ini dapat digunakan untuk melengkapi data desain ketebalan perisai radiasi reaktor.
\end{abstract}

Kata kunci: TRISO, pebble, RDE, laju dosis neutron, ICRP dan NCRP. 


\section{ABSTRACT}

ANALYSIS OF NEUTRON SOURCE STRENGTH AND NEUTRON DOSE RATE CALCULATION OF RDE INITIAL CORE. The reactor core RDE (Experimental Power Reactor) has nonannular cylindrical shape with coated fuel particles TRISO kernel in the spherical form (pebble) and cooled by helium gas. The RDE reactor core design is very safe, because it adopts the hightemperature reactor technology (HTGR) with inherent passive safety. The designed input helium temperature of RDE core is about $250{ }^{\circ} \mathrm{C}$ and the output of helium gas temperature helium of the reactor core of $700{ }^{\circ} \mathrm{C}$. Beside of generating electricity, the $R D E$ reactor is designed to generate high temperature gas that can be used for any purposes such as cogeneration (heat process application research). The spherical fuel called as pebble containing thousand of kernel TRISOcoated fuel particles of uranium dioxide $17 \%\left({ }^{235} \mathrm{U}\right)$ enriched. TRISO coating comprises four layers, namely: porous carbon buffer layer, inner part pyrolytic carbon layer (IPyC, Inner Pyrolitic Carbon), silicon carbide layer (SiC) and a layer of pyrolytic carbon outer part (OPyC, Outer Pyrolitic Carbon). Analysis of neutron source strength and preliminary calculation of neutron dose rate on the RDE core were performed using Monte Carlo MCNP5V1.2 code. Double heterogeneity treatment in TRISO-coated fuel particles kernel and the pebble of the core are applied. Utilization of EGS99304 code to determine 640 amount of energy group structures (SAND-II neutron group structures) are used in the neutron spectrum calculation in the reactor. The reactor core is divided into 100 zones (10 in radial and 10 in axial directions). An analyses calculation result shows that the neutron source strength of the core is about $8.47027 \times 10^{17}$ neutron $/ \mathrm{sec}$. The neutron dose rate distributions are determined using a conversion factor of flux-to-dose taken from International Commission on Radiological Protection (ICRP) and National Council on Radiation Protection and Measurements (NCRP). The preliminary calculations result of neutrons dose rate using ICRP-21 and NCRP-38 conversion factor for radiation workers in the radial direction in the shield biological are already weakened as low as 6.69915 and $6.9964 \mu \mathrm{Sv} / \mathrm{h}$, respectively, at a position of $215 \mathrm{~cm}$ from the center part of the core. This result analysis indicate that radiation workers are safe and protected from neutron radiation sources in accordance with the regulatory requirements. Overall from the calculation and analysis, it appears that the radiation and biological shielding model meets to the standards of radiation safety required. The results of this study can be used to complete the design data thickness of shielding of the reactor.

Keywords: TRISO, pebble, RDE, neutron dose rate, ICRP and NCRP. 


\section{PENDAHULUAN}

Reaktor Daya Eksperimental $(\mathrm{RDE})^{[1]}$ merupakan salah satu jenis reaktor temperatur tinggi berpendingin gas helium yang segera akan dibangun di Indonesia, yang mengacu pada desain dan teknologi HTR-10di Cina ${ }^{[2,3,4]}$. Reaktor RDE dirancang menggunakan bahan bakar kernel partikel berlapis (coated fuel particle) TRISO yang berbentuk bola (pebble $)^{[5,6]}$. Dalam operasinya reaktor RDE dapat menggunakan bahan bakar kernel uranium dioksida $\left(\mathrm{UO}_{2}\right)^{[7,8,9]}$, thorium oksida $\left(\mathrm{ThO}_{2} / \mathrm{UO}_{2}\right)^{[10,11,12]}$ maupun plutonium dioksida $\left(\mathrm{PuO}_{2}\right)^{[13,14]}$ tanpa merubah bentuk dan geometri teras reaktor. Pada penelitian ini pembahasan hanya dilakukan terhadap RDE yang menggunakan bahan bakar $\mathrm{UO}_{2}$ dengan pengkayaan ${ }^{235} \mathrm{U}$ sebesar $17 \%$.

Reaktor didisain berdaya termal 10 MWth dengan temperatur keluaran teras sekitar $700{ }^{\circ} \mathrm{C}$ dan menghasilkan listrik sekitar 3 MWe. Di samping menghasilkan listrik, reaktor ini diharapkan dapat menghasilkan panas dengan temperatur tinggi yang dapat digunakan untuk proses panas industri seperti produksi hidrogen dan proses panas lainnya (pencairan batu-bara).

Pengoperasian reaktor RDE-10 (10 MWth) ini harus memenuhi standar batas keselamatan operasi sebuah reaktor nuklir, sehingga penelitian tentang desain perisai radiasi sangat penting untuk dilakukan. Selain batas keselamatan teknis dari reaktor temperatur tinggi tersebut terpenuhi, batas keselamatan operasi juga dimaksudkan untuk keselamatan radiologi[15,16]. Nilai batas keselamatan radiologi yang dipersyaratkan bagi reaktor diantaranya adalah laju dosis radiasi di luar teras reaktor. Nilai batas keselamatan ini tidak boleh dilampaui untuk tujuan keselamatan bagi pekerja radiasi, masyarakat dan lingkungan sekitarnya sehingga penelitian ketebalan perisai radiasi untuk reaktor RDE perlu dilakukan dengan baik dan seksama.
Penelitian laju dosis neutron dimulai dari pemodelan partikel kernel berlapis TRISO, bahan bakar bola (pebble-bed) dan pemodelan teras beserta reflektor dan perisai radiasinya. Perhitungan kuat sumber neutron yang dibangkitkan oleh teras reaktor dapat dilakukan selanjutnya. Dengan memanfaatkan suatu program Monte Carlo MCNP5v1.2 dalam pemodelan sumber radiasi, maka dilakukan modifikasi pada hasil keluaran yang diinginkan yaitu dengan menambahkan tally ternormalisasi kuat sumber dan tally energi. Tally merupakan bahasa Monte Carlo MCNP untuk menyebutkan besaran fisika yang diinginkan. Penambahan tally ini akan memberikan keluaran berupa spektrum energi dari sebuah sumber radiasi. Semua perhitungan dilakukan pada teras awal yang menggunakan bahan bakar segar (fresh fuel). Status penelitian sebelumnya telah dilakukan perhitungan laju dosis pada reaktor tipe HTGR pebble-bed dengan daya 200 MWth (RGTT200K) ${ }^{[17]}$ dengan hasil yang sesuai dengan rekomendasi Perka BAPETEN No. 4 tahun 2013.

Pendefinisian sumber radiasi dibutuhkan nilai kuat sumber (source strength) yang digunakan untuk menormalisasi nilai-nilai keluaran dari Monte Carlo MCNP5v1.2. Jika sumber radiasi berbentuk zat radioaktif maka nilai kuat sumber merupakan nilai aktivitas dalam satuan Becquerel (Bq) atau Currie (Ci). Namun, dalam pemodelan ini sumber radiasi dari reaktor adalah hasil reaksi fisi yang terjadi di dalam bahan bakar bola, tepatnya pada partikel kernel bahan bakar berlapis TRISO. Radiasi neutron yang akan dihitung nilai dosisnya merupakan hasil reaksi fisi yang terjadi pada kernel bahan bakar TRISO tersebut. Oleh karena itu kuat sumber dari model sumber radiasi merupakan jumlah partikel neutron per satuan waktu hasil reaksi fisi yang terjadi pada daya reaktor tertentu, dalam hal ini daya reaktor ditentukan $10 \mathrm{MWth}$. Nilai kuat sumber diperoleh 
dari perhitungan jumlah reaksi fisi yang diperlukan untuk menghasilkan daya setiap Watt-nya.

Dalam penelitian ini pemanfaatan metode probabilistik dengan program Monte Carlo MCNP5v1.2 dengan memanfaatkan tampang lintang energi kontinu yang dibangkitkan dari file data nuklir ENDF/B-VII. Program Monte Carlo MCNP5v1.2 merupakan program komputer berbasis Monte Carlo yang dapat diaplikasikan untuk mensimulasikan perjalanan partikel yaitu neutron, foton, dan elektron. Program ini telah dikembangkan oleh Tim Monte Carlo X-5 (2003) dari LANL (Los Alamos National Laboratory) - Amerika Serikat.

Untuk melakukan analisis kuat sumber menggunakan program Monte Carlo MCNP5v1.2 diperlukan parameter input yaitu geometri, posisi sumber radiasi yang berupa reaksi fisi dalam kernel TRISO, jumlah kelompok energi ditentukan dengan menggunakan energy group structure yang sesuai dengan spektrum neutron reaktor jenis HTGR (High Temperature Gas Cooled Reactor) yang akan dibangkitkan dengan program EGS99304. Data geometri lainnya yang dimasukkan sebagai parameter input meliputi ukuran kernel bahan bakar berlapis TRISO, pebble, teras, gas pendingin helium dan reflektor serta perisai radiasi dan perisai biologis ${ }^{[18,19]}$.

Penggunaan program Monte Carlo MCNP/MCNPX selain perhitungan neutronik $^{[20,21]}$ seperti parameter kritikalitas, dapat juga digunakan untuk perhitungan laju dosis neutron meupun gamma dengan menambahkan kartu tally khusus seperti Tally Fluks F4 (Flux over a cell), Tally DE (Dose Energy) dan Tally $D F(E)$ yang dimanfaatkan untuk mengkonversi dari fluks ke dosis dengan faktor tertentu sesuai dengan besaran faktor konversi yang diperoleh dari referensi ICRP-21 (1971) dan NCRP-38, ANSI/ANS-6.1.1-1977[22]. Penambahan tally ini akan memberikan keluaran berupa laju dosis (Sv/jam atau rem/jam) yang dihasilkan pada posisi tertentu pada geometri teras reaktor. Hasil dari penelitian ini dapat digunakan untuk menentukan desain ketebalan perisai radiasi hingga perisai biologis sehingga distribusi radiasi neutron yang menyebar ke seluruh daerah di sekitar reaktor dapat diprediksi dan aman bagi pekerja radiasi. Untuk menurunkan dosis radiasi neutron, maka di sekitar teras reaktor tersebut dipasang perisai radiasi dan perisai biologis yang aman untuk operasional reaktor yang memenuhi standar keselamatan radiasi yang dipersyaratkan oleh peraturan yang berlaku.

\section{DESKRIPSI BAHAN BAKAR PEBBLE}

llustrasi bahan bakar teras reaktor RDE, mengikuti bentuk dan geometri bahan bakar HTR-10 yang berupa kernel uranium dioksida $\left(\mathrm{UO}_{2}\right)$ berlapis TRISO seperti Gambar 1 dan Tabel 1, yang mengadopsi dari reaktor HTR-10 Cina.

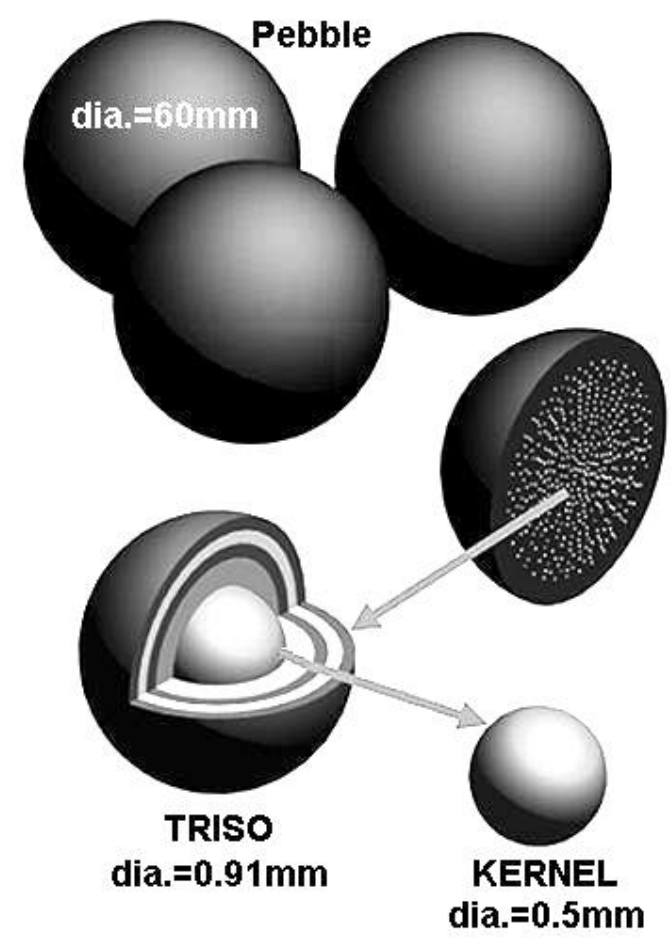

Gambar 1. llustrasi bahan bakar yang digunakan pada reaktor RDE [23]. 
Tabel 1. Spesifikasi teknis bahan bakar TRISO dan pebble untuk teras RDE[1,21].

\begin{tabular}{|l|c|}
\hline \multicolumn{2}{|l|}{ PARTIKEL BERLAPIS TRISO (Coated Fuel Particles) } \\
\hline - Material kernel bahan bakar & $\mathrm{UO}_{2}$ \\
\hline - Diameter kernel, $\mathrm{cm}$ & 0,05 \\
\hline - Pengkayaan, $\%$ (235) $^{235}$ & 17 \\
\hline - Densitas kernel, $\mathrm{g} / \mathrm{cm}^{3}$ & 10,4 \\
\hline - Diamater total kernel + TRISO, $\mathrm{cm}$ & 0,091 \\
\hline Pelapisan(Coating layer) & \\
\hline - Material lapisan/coating (dimulai dari kernel)) & $\mathrm{C} / \mathrm{IPyC} / \mathrm{SiC} / \mathrm{OPyC}$ \\
\hline - Ketebalan lapisan/coating, $\mathrm{cm}$ & $0,009 / 0,0040 / 0,0035 / 0,004$ \\
\hline - Densitas lapisan/coating, $\mathrm{g} / \mathrm{cm}^{3}$ & $1,05 / 1,90 / 1,38 / 1,90$ \\
\hline BAHAN BAKAR PEBBLE & \\
\hline - Diameter pebble, cm & 6,00 \\
\hline - Diameter daerah aktif bahan bakar, $\mathrm{cm}$ & 5,00 \\
\hline - Tebal matriks grafit outer shell, cm & 0,50 \\
\hline - Densitas matrik grafit outer shell, $\mathrm{g} / \mathrm{cm}^{3}$ & 1,75 \\
\hline
\end{tabular}

Tabel 2. Spesifikasi beton yang digunakan dalam disain perisai biologis teras $\operatorname{RDE}^{[23]}$.

\begin{tabular}{|c|c|c|c|c|}
\hline \multicolumn{5}{|c|}{ Densitas beton: $2,25 \mathrm{~g} / \mathrm{cm}^{3}$} \\
\hline Nuklida & $\begin{array}{l}\text { Abundansi } \\
\text { (\%) }\end{array}$ & MCNP-ID & \%berat & $\begin{array}{l}\text { Densitas Atom } \\
\text { (atom/barn.cm) }\end{array}$ \\
\hline $\mathrm{H}-1$ & 99,9987 & 1001 & 0,00453 & $6,09400 \mathrm{E}-03$ \\
\hline $0-16$ & 99,7570 & 8016 & 0,51260 & $4,34210 \mathrm{E}-02$ \\
\hline Si-28 & 92,2230 & 14000 & 0,36036 & 1,73900E-02 \\
\hline Al-27 & 100 & 13027 & 0,03555 & $1,78600 \mathrm{E}-03$ \\
\hline $\mathrm{Na}-23$ & 100 & 11023 & 0,01527 & $9,00000 \mathrm{E}-04$ \\
\hline Ca-40 & 96,9410 & 20000 & 0,05791 & $1,95800 \mathrm{E}-03$ \\
\hline $\mathrm{Fe}-56$ & 91,7540 & 26000 & 0,01378 & $3,34000 \mathrm{E}-04$ \\
\hline \multicolumn{3}{|c|}{ JUMLAH } & 1,00000 & $7,18830 \mathrm{E}-02$ \\
\hline
\end{tabular}

Untuk komposisi material pada perisai biologis dari beton setebal $100 \mathrm{~cm}$ yang digunakan dalam perhitungan dengan memanfaatkan data referensi beton dari Los Alamos National Laboratory (LANL) - USA, seperti di sajikan dalam Tabel 2.

\section{METODOLOGI}

Metodologi yang digunakan adalah perhitungan, dimana perhitungan dimulai dari menghitung komposisi dan densitas semua material penyusun komponen partikel kernel TRISO, pebble, teras, pendingin helium, reflektor dan perisai radiasi. Langkah selanjutnya melakukan pemodelan geometri partikel kernel bahan bakar berlapis TRISO dan bahan bakar pebble menggunakan program Monte Carlo MCNP5v1.2 dengan memanfaatkan tampang lintang data nuklir energi kontinu ENDF/B-VII, dan memperhatikan fraksi packing ${ }^{[24,25]}$ pada bahan bakar pebble yang digunakan. Pemodelan teras reaktor beserta batang kendali, kanal helium dan konus pengeluaran bahan bakar pebble menggunakan Monte Carlo MCNP5v1.2 dengan memanfaatkan tampang lintang enegi kontinyu ENDF/B-VII. Penentuan jumlah kelompok energi / jumlah group structure yang sesuai dengan spektrum pada reaktor menggunakan program EGS99304. Pemodelan perisai radiasi hingga perisasi biologis reaktor untuk penentuan kuat sumber 
neutron (neutron source strength) dan penentuan awal laju dosis neutron yang dipancarkan oleh sumber neutron dengan kartu tally yang tersedia dalam program Monte Carlo MCNP5v1.2 yang disesuaikan dengan faktor konversi fluks neutron ke dalam laju dosis neutron menurut referensi ICRP-21 dan NCRP-38, ANSI/ANS-6.1.11977.

\section{a. Pemodelan kernel partikel berlapis TRISO dan pebble}

Pemodelan bahan bakar pertikel berlapis TRISO dalam program Monte Carlo MCNP5v1.2 dilakukan dengan membagi bahan bakar pertikel berlapis TRISO menjadi enam zona dimulai dari dalam yaitu: zona 1 berisi kernel $\mathrm{UO}_{2}$, zona 2 berisi lapisan buffer yang terbuat dari grafit berpori besar, zona 3 berisi lapisan pirolitik-karbon bagian dalam, zona 4 berupa lapisan silikon karbida (SiC), zona 5 berisi lapisan pirokarbon bagian luar dan zona 6 berisi bahan yang berupa matrik grafit. Untuk membentuk bahan bakar pebble yang berisi ribuan bahan bakar partikel berlapis berdiameter $2,5 \mathrm{~cm}$ yang seragam, maka diperlukan pola penyusunan bahan bakar partikel berlapis TRISO menggunakan fraksi packing sebesar $5 \%$. Bola bahan bakar tersebut yang sudah berisikan ribuan partikel TRISO kemudian dilapisi lagi dengan shell grafit bagian luarnya setebal $0,5 \mathrm{~cm}$ sehingga membentuk bahan bakar berbentuk bola (pebble-bed) dengan ukuran sebesar bola tenis dengan diameter $6 \mathrm{~cm}$.

Bahan bakar pebble tersebut kemudian dimasukkan ke dalam teras reaktor dengan memodelkan terlebih dahulu menggunakan kisi BCC (Body Centered Cubic) sedemikian rupa sehingga diperoleh fraksi packing sebesar $61 \%$ (nilai optimal untuk HTGR berbahan bakar pebble). Penerapan heterogenitas ganda pada bahan bakar pebble dan teras dilakukan secara baik menggunakan program Monte Carlo MCNP5v1.2.

\section{b. Pemodelan teras reaktor}

Teras reaktor aktif berbentuk silinder dengan tinggi aktif sekitar $197 \mathrm{~cm}$ dan diameter $180 \mathrm{~cm}$ seperti ditunjukkan pada Gambar 2. Teras reaktor dibagi menjadi 100 zona dengan pembagian 10 zona ke arah radial dan 10 zona ke arah aksial, seperti disajikan dalam Tabel 3.

Tabel 3. Pembagian 100 zona dalam teras reaktor

\begin{tabular}{|c|c|c|c|c|c|c|c|c|c|c|}
\hline $\begin{array}{c}\text { Zona Radial (R) } \\
\text { Zona Aksial (Z) }\end{array}$ & $\mathrm{R} 1$ & $\mathrm{R} 2$ & $\mathrm{R} 3$ & $\mathrm{R} 4$ & $\mathrm{R} 5$ & $\mathrm{R} 6$ & $\mathrm{R} 7$ & $\mathrm{R} 8$ & $\mathrm{R} 9$ & $\mathrm{R} 10$ \\
\hline Z10 & 990 & 991 & 992 & 993 & 994 & 995 & 996 & 997 & 999 & 999 \\
\hline Z9 & 980 & 981 & 982 & 983 & 984 & 985 & 986 & 987 & 989 & 989 \\
\hline Z8 & 970 & 971 & 972 & 973 & 974 & 975 & 976 & 977 & 978 & 979 \\
\hline Z7 & 960 & 961 & 962 & 963 & 964 & 965 & 966 & 967 & 968 & 969 \\
\hline Z6 & 950 & 951 & 952 & 953 & 954 & 955 & 956 & 957 & 958 & 959 \\
\hline Z5 & 940 & 941 & 942 & 943 & 944 & 945 & 946 & 947 & 948 & 949 \\
\hline Z4 & 930 & 931 & 932 & 933 & 934 & 935 & 936 & 937 & 938 & 939 \\
\hline Z3 & 920 & 921 & 922 & 923 & 924 & 925 & 926 & 927 & 928 & 929 \\
\hline Z2 & 910 & 911 & 912 & 913 & 914 & 915 & 916 & 917 & 918 & 919 \\
\hline Z1 & 900 & 901 & 902 & 903 & 904 & 905 & 906 & 907 & 908 & 909 \\
\hline
\end{tabular}




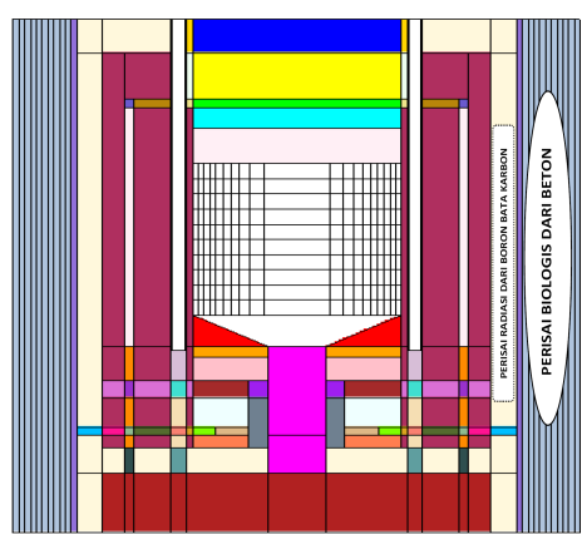

(a) tampak samping

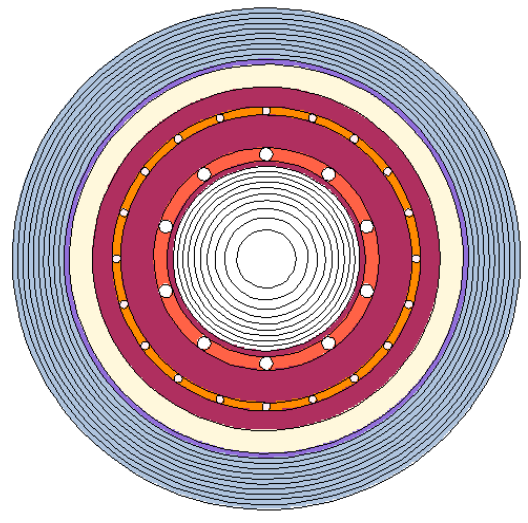

(b) tampak atas

Gambar 2. Pemodelan geometri teras RDE 10MWth dengan Monte Carlo MCNP5v1.2

\section{c. Pemodelan spektrum energi neutron.}

Spektrum neutron rata-rata dalam zona/sel dalam teras dapat ditentukan dengan bantuan menggunakan kartu tally fluks (F4), sementara kartu tally En digunakan untuk mendapatkan fluks neutron rerata yang diperoleh berdasarkan bin energi yang dipilih yaitu sebanyak 640 kelompok energi (SAND-II group structure) yang diperoleh dari program program EGS99304.

Distribusi spektrum neutron digunakan untuk menghitung fluks neutron yang dibangkitkan teras awal dengan bahan bakar segar (fresh fuel) pada rentang energi $10^{-9} \mathrm{MeV}$ hingga $20 \mathrm{MeV}$. Distribusi

$\mathrm{CF}=\left(\frac{1 \text { joule } / \text { detik }}{\text { watt }}\right)\left(\frac{1 \mathrm{MeV}}{1,602 \times 10^{-13} \text { joule }}\right)\left(\frac{\text { fisi }}{180 \mathrm{MeV}}\right)=3,47 \times 10^{10}$ fisi $/$ watt.detik

Kuat Sumber Neutron (Neutron Source Strength, NSS) biasanya didefinisikan sebagai jumlah populasi neutron sesaat (instantaneous neutron population) yang dihasilkan dalam reaksi fisi dalam waktu satu detik.

$\mathrm{NSS}=\mathrm{P} \times \mathrm{CF} \times \bar{v}$

dengan:

$\begin{aligned} \text { NSS } & \begin{array}{l}\text { Neutron Source Strength } \\ (\text { neutron/detik })\end{array} \\ \mathrm{P} & =\text { Daya termal reaktor } \mathrm{RDE}=10\end{aligned}$

spektrum neutron maksimum terjadi pada teras reaktor RDE bagian tengah yaitu sebesar $4,37910 \times 10^{19} 1 / \mathrm{cm}^{2}$.detik.MeV pada energi neutron sekitar $3,6 \times 10^{-8} \mathrm{MeV}$ $(0,036 \mathrm{eV})$.

\section{d. Kuat sumber neutron}

Kuat sumber neutron pada teras awal reaktor berbahan bakar segar (fresh fuel) berdaya termal $10 \mathrm{MW}$ th dihitung menggunakan persamaan konversi. Nilai kuat sumber diperoleh dari perhitungan jumlah reaksi fisi yang diperlukan untuk menghasilkan daya setiap Watt-nya. Untuk mendapatkan nilai tersebut digunakan persamaan konversi, (CF) sebagai berikut ${ }^{[17]}$ : 
dihasilkan pada teras awal ditentukan menggunakan persamaan berikut ${ }^{[17]}$ :

$\Phi\left[\frac{\text { neutron }}{\mathrm{cm}^{2} \cdot \text { detik }}\right]=$ Tally $F 4\left(\Phi_{F 4}\right)\left(1 / \mathrm{cm}^{2}\right) *$ NSS (neutron/detik) * $\frac{1}{k_{\text {eff }}}$

dengan:

Tally F4 (ФF4)

=hasil output perhitungan MCNP (1/cm2),

$k_{\text {eff }}=$ nilai konstanta multiplikasi/ perlipatan neutron efektif,

NSS = Neutron Source Strength (kuat sumber neutron) dalam (neutron/detik)

\section{HASIL DAN PEMBAHASAN}

Nilai kuat sumber neutron reaktor RDE pada teras awal diperoleh dengan menggunakan persamaan (1) dan persamaan (2), serta nilai keluaran dari MCNP untuk jumlah rerata neutron diproduksi per fission $(\bar{v})$ yang terjadi sebesar 2,4410 neutron/fisi adalah:

$$
\begin{aligned}
\text { NSS RDE } & =10^{7} \text { (watt) } \times 3.47 \times 10^{10} \text { (fisi/watt.detik) } \times 2,4410 \text { (neutron/fisi) } \\
& =8,47027 \times 10^{17} \text { neutron/detik }
\end{aligned}
$$

Untuk menentukan laju dosis neutron yang dihasilkan dari teras awal RDE dihitung dari fluks neutron rata-rata dalam teras awal RDE menggunakan persamaan (3) dan dikonversikan ke dalam laju dosis neutron menggunakan faktor konversi yang diperoleh dari referensi NCRP-38, ANSI/ANS-6.1.1-1977 dan ICRP-21 seperti yang disajikan dalam Tabel 4 .

Tabel 4. Faktor konversi fluks neutron ke dalam dosis neutron[19]

\begin{tabular}{|c|c|c|}
\hline \multirow{2}{*}{\begin{tabular}{c} 
Energi, \begin{tabular}{c} 
(MeV) \\
\cline { 2 - 3 }
\end{tabular} \\
\cline { 2 - 3 }$(\mathrm{rem} / \mathrm{jam})\left(\mathrm{n} / \mathrm{cm}^{2} \cdot\right.$ detik $)$
\end{tabular}} & $\begin{array}{c}\text { ICRP-21 } \\
\text { (rem/jam) }\left(\mathrm{n} / \mathrm{cm}^{2} \text {.detik }\right)\end{array}$ \\
\hline $2,5 \mathrm{E}-08$ & $3,67 \mathrm{E}-06$ & $3,85 \mathrm{E}-06$ \\
\hline $1,0 \mathrm{E}-07$ & $3,67 \mathrm{E}-06$ & $4,17 \mathrm{E}-06$ \\
\hline $1,0 \mathrm{E}-06$ & $4,46 \mathrm{E}-06$ & $4,55 \mathrm{E}-06$ \\
\hline $1,0 \mathrm{E}-05$ & $4,54 \mathrm{E}-06$ & $4,35 \mathrm{E}-06$ \\
\hline $1,0 \mathrm{E}-04$ & $4,18 \mathrm{E}-06$ & $4,17 \mathrm{E}-06$ \\
\hline $1,0 \mathrm{E}-03$ & $3,76 \mathrm{E}-06$ & $3,70 \mathrm{E}-06$ \\
\hline $1,0 \mathrm{E}-02$ & $3,56 \mathrm{E}-06$ & $3,57 \mathrm{E}-06$ \\
\hline $1,0 \mathrm{E}-01$ & $2,17 \mathrm{E}-05$ & $2,08 \mathrm{E}-05$ \\
\hline $5,0 \mathrm{E}-01$ & $9,26 \mathrm{E}-05$ & $7,14 \mathrm{E}-05$ \\
\hline 1,0 & $1,32 \mathrm{E}-04$ & $1,18 \mathrm{E}-04$ \\
\hline 2,0 & - & $1,43 \mathrm{E}-04$ \\
\hline 2,5 & $1,25 \mathrm{E}-04$ & - \\
\hline 5,0 & $1,56 \mathrm{E}-04$ & $1,47 \mathrm{E}-04$ \\
\hline 7,0 & $1,47 \mathrm{E}-04$ & - \\
\hline 10,0 & $1,47 \mathrm{E}-04$ & $1,47 \mathrm{E}-04$ \\
\hline 14,0 & $2,08 \mathrm{E}-04$ & - \\
\hline 20,0 & $2,27 \mathrm{E}-04$ & $1,54 \mathrm{E}-04$ \\
\hline
\end{tabular}

Perhitungan awal laju dosis dilakukan menggunakan Tally F4 (Flux over surface), Tally DE (Dose Energy) dan Tally $D F(E)$ untuk mengkonversi dari fluks ke dosis dengan faktor tertentu sesuai dengan besaran faktor konversi yang diperoleh dari beberapa referensi. Komisi Internasional untuk Proteksi Radiasi (International Commission on Radiological Protection, ICRP), yaitu ICRP-21 (1971) dan NCRP-38, ANSI/ANS-6.1.1-1977. Penambahan tally ini (DE dan DF) akan memberikan keluaran 
berupa laju dosis (Sv/jam atau rem/jam) yang dihasilkan pada posisi tertentu pada geometri teras reaktor dengan normalisasi terhadap nilai kuat sumber neutron yang telah diperoleh tersebut (sebagai tally FM). menggunakan bahan bakar $\mathrm{UO}_{2}$ pengkayaan ${ }^{235} \mathrm{U}$ sebesar $17 \%$, dengan faktor konversi fluks neutron ke laju dosis sesuai dengan referensi ICRP-21 (1971) dan NCRP-38, ANSI/ANS-6.1.1-1977.

Perhitungan awal laju dosis yang dibangkitkan oleh teras RDE 10 MWth yang

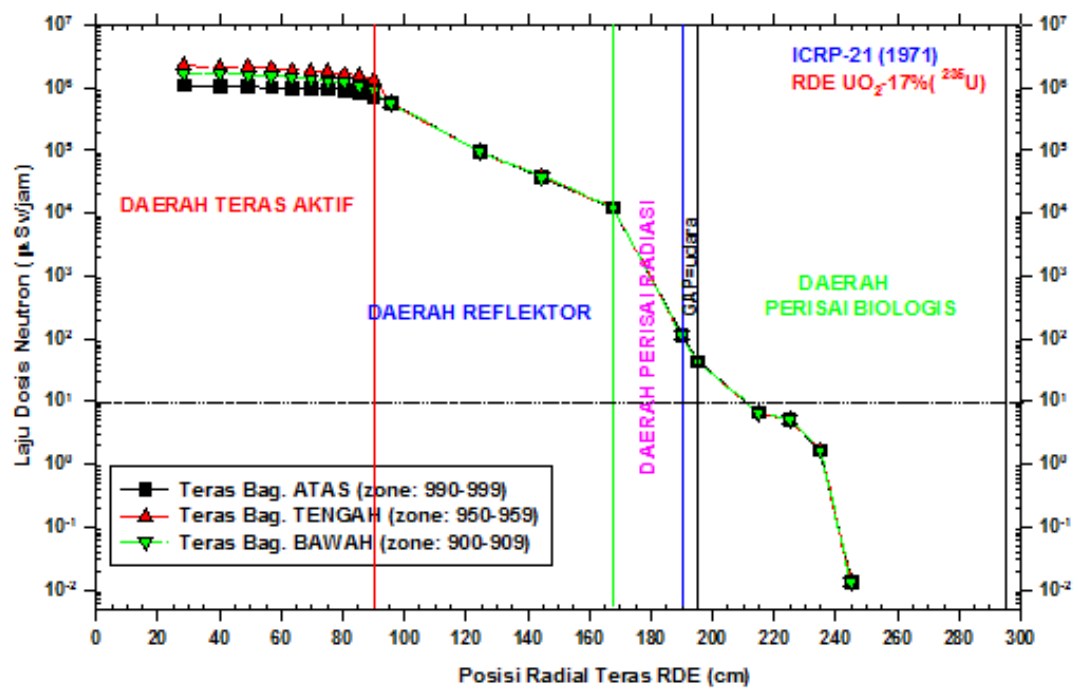

Gambar 4. Hasil perhitungan distribusi laju dosis neutron teras awal RDE menggunakan konversi ICRP-21 (1971).

Semua nilai hitung diperoleh dari perhitungan dengan menggunakan program Monte Carlo MCNP5v1.2, dengan Tally Fluks (Tally F4) dan faktor konversi Flux-to-Dose dikalikan dengan Nilai Kuat Sumber (NSS), sehingga diperoleh distribusi laju dosis neutron teras RDE seperti yang erlihat pada Gambar 4. Laju dosis neutron pada Gambar 4 menggunakan faktor konversi fluks ke dalam dosis neutron dari ICRP21 (1971), sedangkan pada Gambar 5 menggunakan faktor konversi fluks neutron ke dalam dosis neutron menurut NCRP-38, ANSI/ANS-6.1.1-1977.

Berdasarkan peraturan terbaru Perka BAPETEN No. 4 tahun 2013 tentang Proteksi Dan Keselamatan Radiasi Dalam Pemanfaatan Tenaga Nuklir, NBD (Nilai Batas Dosis) efektif rerata untuk pekerja radiasi ditetapkan $20 \mathrm{mSv}$ (2000 mrem) per tahun atau $0,01 \mathrm{mSv} / \mathrm{jam}$ ( 1 tahun pekerja radiasi $=(8$-jam $) \times(5$-hari $) \times(50$-minggu $)=$ $2000 \mathrm{jam}$ ) atau setara dengan $10 \mu \mathrm{Sv} / \mathrm{jam}$. 


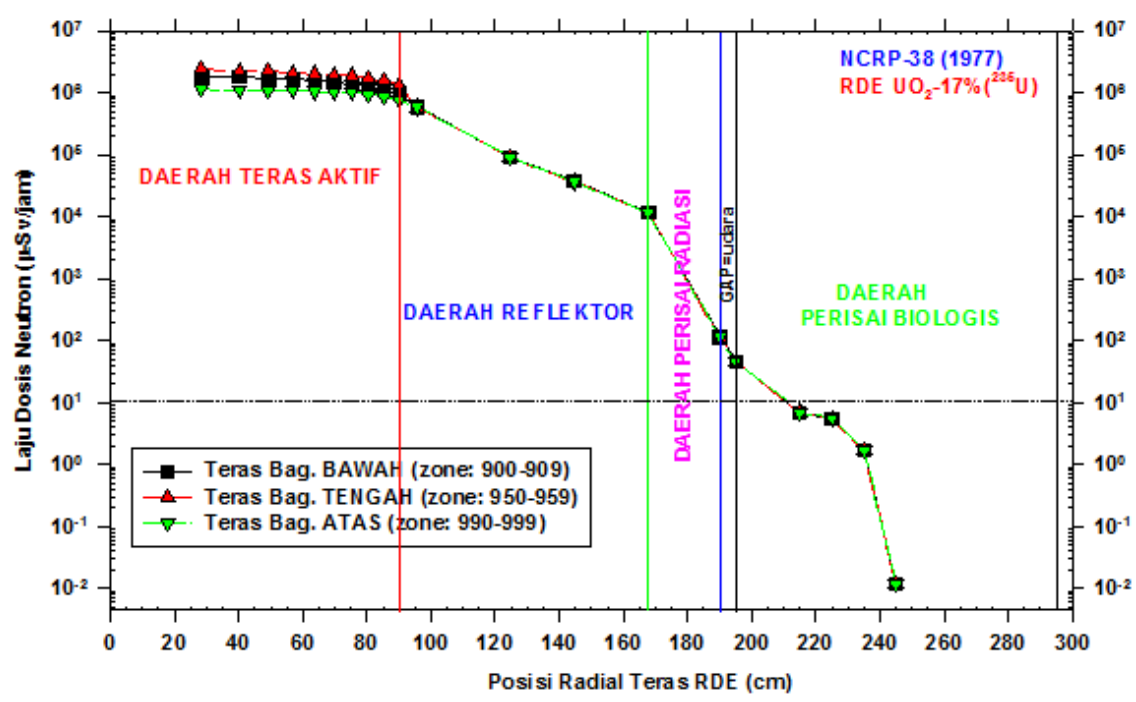

Gambar 5. Hasil perhitungan distribusi laju dosis neutron teras awal RDE menggunakan konversi NCRP-38, ANSI/ANS-6.1.1-1977.

Dari Gambar 4 dan 5, tampak bahwa pada arah aksial bagian tengah teras memiliki laju dosis neutron yang paling tinggi dibanding pada bagian bawah dan atas teras reaktor. Pada jarak radial $215 \mathrm{~cm}$ dari pusat teras RDE (ketebalan perisai biologis $20 \mathrm{~cm}$ ), laju dosis neutron sudah melemah hingga 6,69915 $\mu \mathrm{Sv} / \mathrm{jam}$ dengan konversi ICRP-21 sedang-kan dengan NCRP-38, ANSI/ANS-6.1.1-1977 adalah 6,9964 $\mu \mathrm{Sv} / \mathrm{jam}$. Pada kedua perhitungan laju dosis neutron yang dilaku-kan pada ketebalan perisai biologis $50 \mathrm{~cm}$ (jarak radial dari pusat teras $50 \mathrm{~cm}$ ) sudah sangat kecil yaitu 0,01129 dan 0,01150 $\mu$ Sv/jam, masingmasing untuk ICRP-21 dan NCRP-38, ANSI/ANS-6.1.1-1977.

Dengan kedua faktor konversi Fluxto-dose yang digunakan telah memenuhi persyaratan yang berlaku yaitu Perka BAPETEN No. 4 tahun 2013. Hasil perhitungan dan analisis menggunakan ICRP-21 menunjukkan hasil yang lebih konservatif. Dengan demikian dapat dikatakan bahwa desain ketebalan perisai biologis yang dimodelkan sudah mencukupi dan aman bagi pekerja radiasi, sehingga pekerja radiasi aman dan terlindungi dari sumber radiasi neutron.

\section{SIMPULAN}

Hasil perhitungan memberikan nilai kuat sumber neutron (NSS, Neutron Source Strength) yang dihasilkan oleh teras RDE sebesar 10 MWth adalah $8,47027 \times 10^{17}$ neutron/detik, dengan nilai jumlah neutron setiap kejadian fisi pembelahan sebesar 2,4410 neutron/fisi.

Dengan menggunakan faktor konversi fluks ke dalam laju dosis sesuai referensi ICRP-21 dan NCRP-38, diperoleh hasil perhitungan laju dosis neutron untuk teras RDE pada daerah di luar teras di posisi radial $215 \mathrm{~cm}$ (ketebalan perisai biologis $20 \mathrm{~cm}$ ) dari pusat teras RDE sudah memenuhi persyaratan yang ditentukan oleh Perka BAPETEN No. 4 tahun 2013, sehingga pekerja radiasi aman dan terlindungi dari radiasi neutron.

\section{UCAPAN TERIMA KASIH}

Penulis mengucapkan terima kasih kepada Dr. Jupiter Sitorus Pane, M.Sc. selaku Kepala Bidang Fisika dan Teknologi Reaktor (BFTR) dan Dr. Topan Setiadipura, atas saran dan perbaikan, sehingga makalah ini dapat ditulis dan diselesaikan dengan baik. Dorongan semangat dan bantuan serta 
diskusi dari rekan BFTR sangat kami hargai. Penelitian ini sepenuhnya dibiayai oleh DIPA PTKRN tahun 2015.

\section{DAFTAR PUSTAKA}

[1] Tim Penyusun Dokumen Spesifikasi Teknis RDE. (2014). Dokumen Spesifikasi Teknis Reaktor Daya Eksperimental. Nomor Idetifikasi Dokumen: DT.002.KRN.2014, Rev.0, tanggal: 20-Nov-2014, PTKRNBATAN, Tangerang Selatan.

[2] Meng-Jen Wang, Rong-Jiun Sheu, Jinn-Jer Peir, Jenq-Horng Liang. (2014). Criticality Calculations of the HTR-10 Pebble-bed Reactor with SCALE6/CSAS6 and MCNP5. Journal of Annals of Nuclear Energy 64, 1-7.

[3] Fubing Chen, Yujie Dong, Yanhua Zheng, Lei Shi and Zuoyi Zhang. (2009). Benchmark Calculation for the Steady-State Temperature Distribution of the HTR-10 under FullPower Operation. Journal of Nuclear Science and Technology, Vol. 46, No. 6, p. 572-580.

[4] Rosales, J., A. Muñoz, C. García, L. García, C. Brayner, J. Pérez, and A. Abánades. (2014). Computational Model for the Neutronic Simulation of Pebble Bed Reactor's Core Using MCNPX. Hindawi Publishing Corporation, International Journal of Nuclear Energy, Volume 2014, Article ID 279073, 12 pages, http://dx.doi.org/ $10.1155 / 2014 / 279073$.

[5] Kania, M. J., Nabielek, H. and Nickel, H. (2015). Coated Particle Fuels for High Temperature Reactors. Journal of Materials Science and Technology, DOI: $10.1002 / 9783527603978 . \quad$ Mst 0449, p.1-18.

[6] K. Verfondern, H. Nabielek and J. M. Kendall. (2007). Coated Particle Fuel For High Temperature Gas Cooled
Reactors. Journal of Nuclear Engineering and Technology, Vol.39 No.5, 603-616.

[7] Malin Liu, Bing Liu, Youlin Shao. (2012). Optimization of the $\mathrm{UO}_{2}$ kernel coating process by $2 D$ simulation of spouted bed dynamics in the coater. Journal of Nuclear Engineering and Design 251, 124-130.

[8] Michael J. Kania, Heinz Nabielek, Karl Verfondern, Hans-Josef Allelein. (2013). Testing of HTR UO $\mathrm{U}_{2}$ TRISO Fuels in AVR and in Material Test Reactors. Journal of Nuclear Materials 441, 545-562.

[9] Hoai Nam Tran, Van Khanh Hoang. (2012). Neutronic Characteristics of an OTTO Refueling PBMR. Journal of Nuclear Engineering and Design 253, $269-276$.

[10] H.J. Allelein, M.J. Kania, H. Nabielek, K. Verfondern. (2014). Thorium Fuel Performance Assessment in HTRs. Nuclear Engineering and Design 271, 166-170.

[11] Piyatida Trinuruk, Toru Obara. (2015). Particle-Type Burnable Poisons for Thorium-Based Fuel in HTGR. Energy Procedia 71, 22 - 32.

[12] F.J. Wols, J.L. Kloosterman, D. Lathouwers, T.H.J.J. van der Hagen.(2014). Core Design and Fuel Management Studies of a Thorium Breeder Pebble Bed High Temperature Reactor. Nucl. Technol., 186, pp. 1-16.

[13] J. Jonnet, J.L. Kloosterman, B. Boer. (2010). Performance of TRISO Particles Fueled With Plutonium and Minor Actinides in A PBMR-400 Core Design. Journal of Nuclear Engineering and Design 240,13201331. 
[14] Adem Acir, Hasan Coskun. (2012). Neutronic Analysis of The PBMR-400 Full Core Using Thorium Fuel Mixed With Plutonium or Minor Actinides. Journal of Annals of Nuclear Energy $48,45-50$.

[15] Anonimous. (2013). Perka Kepala BAPETEN Nomor 4 tahun 2013 tentang Proteksi dan Keselamatan Radiasi dalam Pemanfaatan Tenaga Nuklir. Jakarta.

[16] J. Valentin (Ed.). (2012). The 2007 Recommendations of the International Commission on Radiological Protection. p.98 (5.10. Dose Limits), Recommendation No. 244, Elsevier, submitted: March 29.

[17] Suwoto dan Zuhair. (2016). Analisis Laju Dosis Neutron Teras RGTT200K Dengan MCNP5. Jurnal Sains dan Teknologi Nuklir Indonesia, Volume 17 Nomor 2. ISSN 1411-3481. EISSN: 2503-1287. Akreditasi LIPI No. 604/AU3/P2MI-LIPI/03/2015, p.107121

[18] Romolo Remetti, Giulio Andreoli, Silvina Keshishian. (2012). Monte Carlo Calculation of The Neutron Effective Dose Rate at The Outer Surface of The Biological Shield of HTR-10 Reactor. Journal of Nuclear Engineering and Design 243, 148152.

[19] Alia Alizadeh, Amir Saeid Shirani, Samira Kashi. (2013). Neutron and gamma-ray deep penetration calculation through biological concrete shield of VVER-1000 reactor by a new technique based on variance reduction. Journal of Annals of Nuclear Energy 60, 86-92.
[20] J. Rosales, A. Muñoz, C. García, L. García, C. Brayner, J. Pérez, and A. Abánades. (2014). Computational Model for the Neutronic Simulation of Pebble Bed Reactor's Core Using MCNPX. Hindawi Publishing Corporation. International Journal of Nuclear Energy Volume 2014, Article ID 279073, 12 pages.

[21] Hammam Oktajianto, Evi Setiawati, Very Richardina. (2015). Modelling of HTR (High Temperature Reactor) Pebble-Bed 10 MW to Determine Criticality as $A$ Variations of Enrichment and Radius of the Fuel (Kernel) With the Monte Carlo Code MCNP4C. Internat. J. Sci. Eng., Vol. 8(1), 42-46.

[22] X-5 Monte Carlo Team. (2003). MCNP - A General Monte Carlo NParticle Transport Code, Version 5. Vol. I. Overview and Theory, APPENDIX H - FISSION SPECTRA CONSTANTS AND FLUX-TO-DOSE FACTORS, April 24.

[23] RJ Mcconn Jr., et al. (2011). Compendium of Material Composition Data for Radiation Transport Modeling. PIET43741 -TM-963, PNNL-15870 Rev. 1, March 4.

[24] Mehmet Türkmen, Üner Çolak. (2012). Effect of Pebble Packing on Neutron Spectrum and the Isotopic Composition of HTGR Fuel. Journal of Annals of Nuclear Energy 46, 29-36.

[25] F.C. Silva, C. Pereira, M.A.F. Veloso, A.L. Costa. (2012). Shifting study of a VHTR using reprocessed fuel with various TRISO packing fractions. Journal of Nuclear Engineering and Design 248, 42-47. 